\title{
Thioredoxin Reductase 2, Mitochondrial
}

National Cancer Institute

\section{Source}

National Cancer Institute. Thioredoxin Reductase 2, Mitochondrial. NCI Thesaurus. Code C107621.

Thioredoxin reductase 2, mitochondrial ( $524 \mathrm{aa}, \sim 57 \mathrm{kDa}$ ) is encoded by the human TXNRD2 gene. This protein is involved in thioredoxin reduction. 